\title{
ОЦЕНКА СОРТОВ КАРТОФЕЛЯ ДАЛЬНЕВОСТОЧНОЙ СЕЛЕКЦИИ НА ПРИГОДНОСТЬ К ПЕРЕРАБОТКЕ
}

\author{
D.I. Volkov, I.V. Kim,
} A.A. Gisyuk, A.G. Klykov

\section{THE PROSPECTS FOR THE PRODUCTION OF POTATO VARIETIES OF THE FAR EAST SELECTIONS ACCORDING TO THE SUITABILITY FOR PROCESSING}

Волков Дмитрий Игоревич - асп., зав. отделом картофелеводства и овощеводства ФНЦ агробиотехнологий Дальнего Востока им. А.К. Чайки, Приморский край, г. Уссурийск, п. Тимирязевский. E-mail: volkov_dima@inbox.ru

Ким Ирина Вячеславовна - канд. с.-х. наук, вед. науч. сотр. отдела картофелеводства и овощеводства ФНЦ агробиотехнологий Дальнего Востока им. А.К. Чайки, Приморский край, г. Уссурийск, п. Тимирязевский.

E-mail: kimira-80@mail.ru

Гисюк Александр Александрович - лаборантисследователь отдела картофелеводства и овощеводства ФНЦ агробиотехнологий Дальнего Востока им. А.К. Чайки, Приморский край, г. Уссурийск, п. Тимирязевский.

E-mail: volkov_dima@inbox.ru

Клыков Алексей Григорьевич - д-р биол. наук, зав. отделом селекции и биотехнологии сельскохозяйственных культур ФНЦ агробиотехнологий Дальнего Востока им. А.К. Чайки, Приморский край, г. Уссурийск, п. Тимирязевский.

E-mail: volkov_dima@inbox.ru

Цель исследования - изучить и выделить сорта картофеля дальневосточной селекции, пригодные для переработки на картофрелепродукты в условиях муссонного климата. Исследование проводилось в условиях Приморского края в ФГБНУ «ФНЦ агробиотехнологий Дальнего Востока им. А.К. Чайки», на опытном поле с. Пуциловка. Объектом исследования являлись сорта картофреля, созданные в научных учреждениях Дальнего Востока: Дачный, Янтарь, Смак, Казачок, Августин - ФГБНУ «ФНЦ агробиотехнологий Дальнего Востока им. А.К. Чайки»; Арктика, Кольмский, Зоя Магаданский НИИСХ; Камчатка, Солнышко,
Volkov Dmitry Igorevich - Post-Graduate Student, Head, Department of Potato and Vegetable Growing, FRC of Agrobiotechnologies of Far East named after A.K. Chaika, Primorsky Region, Ussuriisk, S. Timiryazevsky.

E-mail: volkov_dima@inbox.ru

Kim Irina Vyacheslavovna - Cand. Agr. Sci., Leading Staff Scientist, Department of Potato and Vegetable Growing, FRC of Agrobiotechnologies of Far East named after A.K. Chaika, Primorsky Region, Ussuriisk, S. Timiryazevsky.

E-mail: kimira-80@mail.ru

Gisyuk Alexander Alexandrovich - Laboratory Research Assistant, Department of Potato and Vegetable Growing, FRC of Agrobiotechnologies of Far East named after A.K. Chaika, Primorsky Region, Ussuriisk, S. Timiryazevsky.

E-mail:volkov_dima@inbox.ru

Klykov Alexey Grigoryevich - Dr. Biol. Sci., Head, Department of Selection and Biotechnology of Crops, FRC of Agrobiotechnologies of Far East named after A.K. Chaika, Primorsky Region, Ussuriisk, S. Timiryazevsky.

E-mail: volkov_dima@inbox.ru

Гейзер, Вулкан - Камчатский НИИСХ; Солнцесвет, Приморский розовый, Приморская заря, Артемовец - Приморская овощная опытная станция, филиал ФГБНУ «Федеральный научный центр овощеводства». В качестве стандарта был взят голландский сорт Сантэ. Высокая урожайность отмечена у сортов Кольмский (75,9 m/2a), Зоя (69,6 m/2a), Дачный $(55,5 \mathrm{~m} / 2 a)$. В результате исследования выделены сорта по размеру клубня (40-60 мм), предпочтительные для переработки на хрустящий картоффель: Августин, Вулкан, Казачок. Размер клубня более 60 мм пригоден для изготовления картофреля фри. Такие пара- 
метры клубней имели сорта: Смак, Дачный, Янтарь. С повышенным содержанием сухого вещества отмечены сортообразцы - Вулкан $(20,01 \%)$, Зоя $(20,85)$, Казачок $(20,05)$, Камчатка $(22,13)$ и Солнышко $(20,14 \%)$. Сорт Кольмский отличился удлиненной формой клубней, рекомендованной для получения фри. Неглубокими и мелкими глазками характеризовались сорта Августин, Артемовеи, Арктика, Вулкан, Гейзер, Зоя, Казачок, Камчатка, Кольмский, Приморская заря, Приморский розовый, Сантэ и Солнцесвет. Не темнеющей мякотью клубней в сыром и вареном виде $(9,0$ баллов) выделены сорта Янтарь и Сантэ. Хорошими и отличными вкусовыми качествами (8,0-9,0 баллов) характеризовались сортообразцы: Августин, Колымский, Приморская заря, Сантэ. Для переработки на хрустящий картофрель рекомендуются сорта Вулкан, Зоя и Казачок. По комплексу ценных признаков для переработки на картофрелепродукты выделены сорта Колымский и Солниесвет.

Ключевые слова: картофрель, сорт, переработка на картофрелепродукты, биохимические показатели, урожайность.

The research objective was to study and allocate the varieties of potatoes of Far East selection suitable for processing for potato products in the conditions of monsoonal climate. The research was conducted in the conditions of Primorsky Region at FSBSI "Federal Research Center for Agrobiotechnologies of the Far East named after A.K. Chaika", on experimental field of the village of Putsilovka. The objects of the research were potatoes varieties created in scientific institutions of the Far East: Dachny, Yantar, Smak, Kazachok, Avgustin - FSBSI "Federal Research Center for Agrobiotechnologies of the Far East named after A.K. Chaika"; Arktika, Kolymsky, Zoya - Magadan Scientific Research Institute; Kamchatka, Solnyshko, Geyzer, Vulkan - Kamchatka Scientific Research Institute of Agriculture; Solntsesvet, Primorsky rozovy, Primorskaya zarya, Artemovets - Primorsky Vegetable Experimental Station, Branch of the Federal Research Center for Vegetable Production". As the standard the Dutch variety Sante was taken. High yields were observed in the varieties Kolymsky (75.9 t/hectare), Zoya (69.6 t / hectare), Dachny (55.5 t/hectare). As a result of the studies the varieties of tuber size $(40-60 \mathrm{~mm})$ were selected that were preferred for processing on crisp: Avgustin, Vulkan, Kazachok. The tuber size more than $60 \mathrm{~mm}$ was suitable for production of French fries. Such parameters of tubers had varieties: Smak, Dachny, Yantar. Varietal samples with an increased dry matter content - Vulcan (20.01\%), Zoya (20.85\%), Kazachok (20.05\%), Kamchatka (22.13\%) and Solnyshko (20.14\%). The variety Kolymsky differed in elongated form of tubers, it was recommended for fries. The varieties Avgustin, Artemovets, Arktika, Vulkan, Geyzer, Zoya, Kazachok, Kamchatka, Kolymsky, Primorskaya zarya, Primorsky rozovy, Sante and Solncesvet were characterized by shallow and small eyes. The varieties Yantar and Sante were characterized by not darkening pulp of tubers in raw and boiled form (9.0 points). The varieties Augustine, Avgustin, Kolymsky, Primorskaya zarya, Sante were characterized by good and excellent taste qualities (8.0-9.0 points). These varieties were recommended for processing on crisp. Kolymsky and Solntsesvet varieties were distinguished by a complex of valuable characteristics for processing into potato products.

Keywords: potatoes, variety, processing for potato products, biochemical parameters, productivity.

Введение. Картофель - важная сельскохозяйственная культура, переработка которой имеет большое значение для решения продовольственной проблемы в РФ и экономики государства в целом. Для успешной промышленной переработки требуются клубни, биологически ценные по качеству. При создании конкретных видов картофелепродуктов необходимы специальные сорта, которые отвечают определенным требованиям и сохраняют свои свойства в течение всего периода хранения [1, 2].

В 2019 г. Государственный реестр селекционных достижений РФ включает 458 сортов картофеля, из них допущенных к использованию в Дальневосточном регионе - 78, в том числе 10 сортов рекомендованы к переработке на различные виды картофелепродуктов (Астерикс, Лига - для производства чипсов; Белоснежка, Брянский деликатес, Накра, Наяда для изготовления хрустящего картофеля; Крепыш, Сантэ, Свитанок киевский, Фреско - универсального назначения) [3]. 
Селекционерами Дальнего Востока за последние 15 лет создано 20 сортов картофеля урожайностью 35,0-40,0 т/га, из них 12 сортов находится в Государственном реестре селекционных достижений РФ и допущены к использованию по Дальневосточному региону.

Приморский край своими природноклиматическими условиями, особенно муссонным типом климата, значительно отличается от других зон выращивания картофеля [4]. В настоящее время в ФНЦ агробиотехнологий Дальнего Востока им. А.К. Чайки проводятся исследования по изучению сортимента картофеля с целью создания и выделения сортов, пригодных на переработку с получением картофелепродуктов.

Цель исследования: оценить и выделить сорта картофеля дальневосточной селекции, пригодные для переработки на картофелепродукты в условиях муссонного климата.

Объекты и методы исследования. Исследование проводилось в отделе картофелеводства и овощеводства ФГБНУ «ФНЦ агробиотехнологий Дальнего Востока им. А.К. Чайки». В 2019 г. изучено 17 сортов картофеля дальневосточной селекции: Янтарь, Дачный, Смак, Казачок, Августин - ФГБНУ «ФНЦ агробиотехнологий Дальнего Востока им. А.К. Чайки»; Арктика, Колымский, Зоя - Магаданским НИИСХ; Камчатка, Солнышко, Гейзер, Вулкан - Камчатским НИИСХ; Солнцесвет, Приморский розовый, Приморская заря, Артемовец - Приморской овощной опытной станцией, филиалом ФГБНУ «Федеральный научный центр овощеводства». В качестве стандарта был взят голландский сорт Сантэ, который рекомендован для переработки на картофелепродукты. Изучаемые образцы располагались в коллекционном питомнике на 5-рядковых делянках (10 клубней в одном ряду). Площадь питания - $90 \times 30$ см. Повторность однократная. Уход за посадками картофеля проводили по общепринятой для Приморского края агротехнике.

За основу в исследованиях были приняты Методические рекомендации по специализированной оценке сортов картофреля (Минск, 2003) [5]; Методические указания по технологии селекционного процесса картофеля (М., 2006) [6]; Методические указания по оценке сортов картофеля на пригодность к переработке и хранению (М., 2008) [7]. Методические указания по поддержанию и изучению мировой коллекции картофреля (СПб., 2010) [8].

Морфологические признаки (форма и размер клубня, глубина глазков и их количество, поверхность клубня) определяли у каждого образца путем измерения 20 клубней [7].

Биохимический анализ проводили в агрохимлаборатории ФГБНУ «ФНЦ агробиотехнологий Дальнего Востока им. А.К. Чайки» $[9,10]$.

Во время уборки учитывали общую массу клубней с делянки, в лабораторных условиях определяли структуру урожая [8].

Потемнение сырой и вареной мякоти определяли в лабораторных условиях после уборки (через 20 мин, 3 ч и 24 ч) по девятибалльной шкале [8].

Результаты исследований и их обсуждение. Особое значение для оценки пригодности сортов к переработке имеют морфологические показатели: форма клубня, качество поверхности, количество глазков и глубина их залегания.

Исследования показали, что индекс фрормы (отношение длины клубня к его ширине) в зависимости от сорта изменялся от 1,09 до 1,77 (табл. 1). Круглую и округло-овальную форму клубня (индекс 1,09-1,39), наиболее предпочтительную для приготовления хрустящего картофеля, имели сорта: Августин, Артемовец, Вулкан, Дачный, Зоя, Казачок, Камчатка, Приморская заря, Приморский розовый, Сантэ (стандарт), Солнышко, Смак, Янтарь. У сорта Колымский форма клубня длинная (индекс составил $1,77)$, что соответствует требованиям для производства картофеля фрри.

В целом для переработки наиболее пригодны клубни с глубиной залегания глазков не более 1,5 мм, так как они хорошо поддаются технологической обработке и дают меньше отходов [5]. Глубина залегания глазков у сортов варьировала от 1,2 до 2 мм, а их среднее количество - от 4,6 до 8,4 шт. Более поверхностным залеганием глазков отличались клубни сортов: Августин, Артемовец, Арктика, Вулкан, Гейзер, Зоя, Казачок, Камчатка, Колымский, Приморская заря, Приморский розовый, Сантэ и Солнцесвет. 
Морфологические признаки клубней сортов картофеля дальневосточной селекции

\begin{tabular}{|c|c|c|c|c|c|c|}
\hline \multirow[t]{2}{*}{ Сорт } & \multicolumn{2}{|c|}{ Индекс фрормы } & \multirow{2}{*}{$\begin{array}{c}\text { Кол-во } \\
\text { глазков } \\
\text { шт. }\end{array}$} & \multicolumn{2}{|c|}{$\begin{array}{c}\text { Глубина зале- } \\
\text { гания глазков }\end{array}$} & \multirow[t]{2}{*}{$\begin{array}{c}\text { Качество } \\
\text { поверхности } \\
\text { балл } \\
\end{array}$} \\
\hline & коэф. & балл* & & MM & балл & \\
\hline Сантэ, st & 1,29 & 7 & 5,4 & 1,4 & 5 & 7 \\
\hline \multicolumn{7}{|c|}{ ФНЦ агробиотехнологий ДВ им. А.К. Чайки } \\
\hline Янтарь & 1,23 & 7 & 8,1 & 1,7 & 3 & 5 \\
\hline Дачный & 1,24 & 7 & 8,0 & 1,7 & 3 & 5 \\
\hline Смак & 1,12 & 7 & 7,2 & 2,0 & 1 & 5 \\
\hline Казачок & 1,17 & 7 & 6,0 & 1,5 & 5 & 5 \\
\hline Августин & 1,29 & 7 & 8,4 & 1,4 & 5 & 5 \\
\hline \multicolumn{7}{|c|}{ ПООС - филиал ФГБНУ ФНЦО } \\
\hline Солнцесвет & 1,45 & 5 & 5,5 & 1,2 & 7 & 7 \\
\hline Приморский розовый & 1,35 & 7 & 7,0 & 1,4 & 5 & 5 \\
\hline Приморская заря & 1,23 & 7 & 6,6 & 1,4 & 5 & 7 \\
\hline Артемовец & 1,21 & 7 & 6,4 & 1,3 & 7 & 5 \\
\hline \multicolumn{7}{|c|}{ Магаданский НИИСХ } \\
\hline Арктика & 1,43 & 5 & 7,6 & 1,5 & 5 & 5 \\
\hline Колымский & 1,77 & 3 & 4,6 & 1,3 & 7 & 7 \\
\hline Зоя & 1,37 & 7 & 6,0 & 1,4 & 5 & 7 \\
\hline \multicolumn{7}{|c|}{ Камчатский НИИСХ } \\
\hline Камчатка & 1,37 & 7 & 7,8 & 1,3 & 7 & 5 \\
\hline Солнышко & 1,09 & 9 & 8,4 & 2,0 & 1 & 3 \\
\hline Гейзер & 1,63 & 5 & 6,9 & 1,4 & 5 & 7 \\
\hline Вулкан & 1,36 & 7 & 5,9 & 1,2 & 7 & 5 \\
\hline
\end{tabular}

Для обеспечения минимального количества отходов при очистке поверхность клубня должна быть ровной и гладкой, без наростов, углублений и ростовых трещин [7]. По данному показателю все сортообразцы, кроме сорта Солнышко (3 балла), имеют поверхность, пригодную для переработки.

Урожайность - основной хозяйственнобиологический признак, определяющий рентабельность производства картофеля. По данным В.Ю. Кордабовского, в условиях севера Дальнего Востока за четыре года испытаний (20122015 гг.) урожайность сортов Арктика, Зоя, Колымский составила 32,$4 ; 33,4$ и 49,3 т/га соответственно [11]. В наших исследованиях урожайность у изучаемых сортов варьировала от 23,9 до 75,9 т/га, 6 сортов достоверно превысили стандартный сорт по этому показателю $(7,9-$ 37,4 т/га) (табл. 2).
Наибольшая урожайность отмечена у сорта Колымский (75,9 т/га), Зоя (69,6 т/га), Дачный (55,5 т/га).

Важное значение для переработки на хрустящий картофель и картофель фрри имеет размер клубня. Наибольшую массу клубней с размером от 40 до 60 мм имели сорта Августин, Казачок, Вулкан $(73,3 ; 67,9 ; 64,0$ \% соответственно), такие клубни наиболее предпочтительны для изготовления хрустящего картофеля. Для получения картофеля фри используют клубни преимущественно размером от 60 мм. По данному показателю выделились сорта Смак (51,1 \% от общего количества клубней в выборке), Дачный $(51,0$ \%), Янтарь (48,7 \%). Наибольшее количество клубней размером менее 40 мм отмечено у сортов Колымский, Приморский розовый (38,4 и 35,8 \% соответственно). 


\section{Структура урожайности и биохимические показатели сортов картофеля}

\begin{tabular}{|c|c|c|c|c|c|c|}
\hline \multirow{3}{*}{ Сорт } & \multirow{3}{*}{$\begin{array}{c}\text { Урожайность, } \\
\text { т/га }\end{array}$} & \multicolumn{3}{|c|}{ Размер фрракций, мм } & \multirow{3}{*}{$\begin{array}{c}\text { Сухое } \\
\text { вещество, } \\
\%\end{array}$} & \multirow{3}{*}{$\begin{array}{l}\text { Редуцирующиє } \\
\text { сахара, \% }\end{array}$} \\
\hline & & менее 40 & $40-60$ & более 60 & & \\
\hline & & \multicolumn{3}{|c|}{$\begin{array}{c}\text { Доля фрракций, \% от общей вы- } \\
\text { борки сорта }\end{array}$} & & \\
\hline Сантэ, st & 38,5 & 10,7 & 53,1 & 36,2 & 16,25 & 0,34 \\
\hline \multicolumn{7}{|c|}{ ФНЦ агробиотехнологий ДВ им. А.К. Чайки } \\
\hline Янтарь & 46,4 & 6,6 & 44,7 & 48,7 & 15,43 & 0,34 \\
\hline Дачный & 55,5 & 13,9 & 39,0 & 47,1 & 16,35 & 0,23 \\
\hline Смак & 26,1 & 8,3 & 40,5 & 51,1 & 17,54 & 0,39 \\
\hline Казачок & 36,3 & 18,1 & 67,9 & 14,0 & 20,05 & 0,31 \\
\hline Августин & 23,9 & 19,2 & 73,3 & 7,5 & 16,99 & 0,18 \\
\hline \multicolumn{7}{|c|}{ ПООС - филиал ФГБНУ ФНЦО } \\
\hline Солнцесвет & 51,8 & 19,3 & 63,3 & 17,4 & 15,89 & 0,50 \\
\hline $\begin{array}{l}\text { Приморский } \\
\text { розовый }\end{array}$ & 29,6 & 35,8 & 59,3 & 4,9 & 16,46 & 0,36 \\
\hline $\begin{array}{l}\text { Приморская } \\
\text { заря }\end{array}$ & 28,3 & 25,6 & 61,6 & 12,8 & 17,85 & 0,22 \\
\hline Артемовец & 40,7 & 11,3 & 37,7 & 51,0 & 16,36 & 0,22 \\
\hline \multicolumn{7}{|c|}{ Магаданский НИИСХ } \\
\hline Арктика & 51,2 & 14,8 & 51,5 & 33,7 & 18,64 & 0,40 \\
\hline Колымский & 75,9 & 38,4 & 51,3 & 10,3 & 14,34 & 0,29 \\
\hline Зоя & 69,6 & 10,8 & 53,9 & 35,3 & 20,85 & 0,27 \\
\hline \multicolumn{7}{|c|}{ Камчатский НИИСХ } \\
\hline Камчатка & 40,1 & 23,6 & 59,5 & 16,9 & 22,13 & 0,32 \\
\hline Солнышко & 38,7 & 7,0 & 59,5 & 33,5 & 20,14 & 0,23 \\
\hline Гейзер & 30,6 & 16,0 & 61,4 & 22,6 & 18,94 & 0,13 \\
\hline Вулкан & 34,8 & 5,1 & 64,0 & 30,9 & 20,01 & 0,32 \\
\hline $\mathrm{HCP}_{05}$ & 5,4 & & & & & \\
\hline
\end{tabular}

Количество сухого вещества в клубнях влияет на выход готовой продукции (расход сырья), расход масла, консистенцию готового продукта, вкус. Для производства хрустящего картофеля и картофеля фри содержание сухих веществ в клубне, исходя из требований, должно быть не ниже $20 \%$ [7].

По данным Т.П. Шестрюковой и А.Д. Иващенко, в условиях Камчатского края (20152018 гг.) повышенным содержанием сухого вещества в клубнях картофеля отличились сортообразцы Вулкан и Гейзер (18,8-18,0 \%) [12]. В наших исследованиях по данному показателю выделились сорта Вулкан (20,01 \%), Зоя $(20,85)$, Казачок $(20,05)$, Камчатка $(22,13)$ и Солнышко $(20,14 \%)$, по сравнению с контрольным сортом, у которого содержание сухого вещества составила $16,25 \%$.

Количество редуцирующих сахаров в клубнях картофеля оказывает существенное влияние на цвет, т. е. на качество обжаренных продуктов. По требованиям, предъявляемым к сортам на переработку, их содержание для получения качественной продукции не должно превышать 0,2-0,4 \% [7]. Большинство изучаемых нами сортов в октябре (после уборки) отвечали этим требованиям.

Одним из важнейших показателей высокого потребительского качества клубней является сохранение характерного для сорта цвета мякоти независимо от вида кулинарной обработки. Развитию потемнения способствуют не только 
варка клубней и последующее их пребывание на воздухе, но и переработка картофеля на готовые картофелепродукты [13, 14].
В послеуборочный период была проведена дегустационная оценка клубней сортов картофеля и изучено их потемнение мякоти в сыром и вареном виде (табл. 3).

Потемнение мякоти и вкус вареных клубней сортов картофеля

Таблица 3

\begin{tabular}{|c|c|c|c|c|c|c|c|}
\hline \multirow{3}{*}{ Сорт } & \multicolumn{6}{|c|}{ Потемнение мякоти, балл } & \multirow{3}{*}{$\begin{array}{l}\text { Вкус, } \\
\text { балл }\end{array}$} \\
\hline & \multicolumn{3}{|c|}{ сырого картофеля } & \multicolumn{3}{|c|}{ вареного картофеля } & \\
\hline & $\begin{array}{c}\text { через } 20 \\
\text { минут }\end{array}$ & 3 часа & 24 часа & $\begin{array}{c}\text { через } 20 \\
\text { минут }\end{array}$ & 3 часа & 24 часа & \\
\hline Сантэ, st & 9 & 8 & 7 & 8 & 7 & 7 & 9,0 \\
\hline \multicolumn{8}{|c|}{ ФНЦ агробиотехнологий ДВ им. А.К. Чайки } \\
\hline Янтарь & 9 & 9 & 8 & 9 & 9 & 7 & 7,6 \\
\hline Дачный & 9 & 8 & 7 & 7 & 6 & 3 & 7,0 \\
\hline Смак & 9 & 7 & 5 & 8 & 7 & 5 & 7,0 \\
\hline Казачок & 9 & 8 & 7 & 9 & 7 & 6 & 7,5 \\
\hline Августин & 8 & 8 & 7 & 9 & 7 & 3 & 8,0 \\
\hline \multicolumn{8}{|c|}{ ПООС-филиал ФГБНУ ФНЦЦО } \\
\hline Солнцесвет & 9 & 6 & 5 & 7 & 7 & 6 & 7,7 \\
\hline $\begin{array}{l}\text { Приморский } \\
\text { розовый }\end{array}$ & 7 & 7 & 7 & 7 & 6 & 5 & 7,0 \\
\hline Приморская заря & 9 & 8 & 6 & 7 & 7 & 6 & 9,0 \\
\hline Артемовец & 9 & 8 & 7 & 6 & 5 & 5 & 7,5 \\
\hline \multicolumn{8}{|c|}{ Магаданского НИИСХ } \\
\hline Арктика & 9 & 9 & 5 & 9 & 8 & 7 & 7,7 \\
\hline Колымский & 9 & 8 & 5 & 7 & 7 & 6 & 8,5 \\
\hline Зоя & 9 & 8 & 8 & 7 & 7 & 6 & 7,8 \\
\hline \multicolumn{8}{|c|}{ Камчатского НИИСХ } \\
\hline Камчатка & 9 & 7 & 7 & 7 & 6 & 6 & 7,7 \\
\hline Солнышко & 8 & 6 & 3 & 7 & 6 & 6 & 9,0 \\
\hline Гейзер & 8 & 8 & 6 & 9 & 7 & 3 & 7,0 \\
\hline Вулкан & 7 & 7 & 6 & 9 & 7 & 6 & 7,5 \\
\hline
\end{tabular}

Проведенный анализ клубней на потемнение мякоти через 24 ч показал очень слабое потемнение у сортов Янтарь, Зоя (8,0 баллов), слабое потемнение - Августин, Артемовец, Дачный, Камчатка, Сантэ, Приморский розовый (7,0 баллов). Наибольшей устойчивостью к потемнению вареного клубня отличились сорта Арктика, Сантэ, Янтарь.

По результатам дегустационной оценки выделены сорта с отличными вкусовыми качествами - Сантэ, Солнышко, Приморская заря - 9,0 баллов; Колымский - 8,5; Августин - 8,0.

\section{Выводы}

В результате изучения 17 сортообразцов картофеля дальневосточной селекции выделись сорта с хозяйственно ценными признаками:

- урожайные (75,9-46,4 т/га) - Арктика, Дачный, Зоя, Колымский, Янтарь;

- с формой клубня, пригодной для переработки на хрустящий картофель (индекс 1,09$1,39)$ - Августин, Артемовец, Вулкан, Дачный, Зоя, Казачок, Камчатка, Приморская заря, Приморский розовый, Смак, Солнышко, Янтарь, в том числе стандартный сорт Сантэ; для изго- 
товления картофеля фрри (индекс 1,7 и более) сорт Колымский;

- с оптимальным количеством глазков на клубне (5-6 шт.) и глубиной их залегания (не более 1,5 мм) - Вулкан, Зоя, Казачок, Колымский, Сантэ, Солнцесвет;

- с высоким содержанием сухого вещества (более 20 \%) - Вулкан, Зоя, Казачок, Камчатка, Солнышко;

- с нетемнеющей мякотью в сыром и вареном виде (8,0-9,0 баллов) - Янтарь, Сантэ;

- с комплексом ценных признаков для переработки на хрустящий картофель - Вулкан, Зоя, Казачок.

Сорта Колымский и Солнцесвет рекомендуется использовать в качестве сортов-источников ценных признаков (высокая урожайность, минимальное количество глазков, поверхность кожуры клубня и его форма) в селекционных программах.

\section{Литература}

1. Симаков Е.А., Анисимов Б.В., Митюшкин А.В. и др. Картофель для переработки: параметры качества, специальные сорта, особенности выращивания. Чебоксары: Астер, 2019. - $40 \mathrm{c}$.

2. Гайзатулин А.С., Митюшкин А.В., Журавлев А.А. и др. Подбор и оценка исходного материала в селекции картофеля на пригодность к переработке // Картофель и овощи. 2019. № 7. С. 36-40.

3. Государственный реестр селекционных достижений. URL: http://reestr.gossortrf.ru/ reestr/culture/159.html (дата обращения: 10.11.2019).

4. Чайка А.К., Клыков А.Г. Приоритетные направления в развитии агропромышленного комплекса Дальнего Востока России // Вестник ДВО РАН. 2016. № 2. С. 24-30.

5. Методические рекомендации по специализированной оценке сортов картофеля / сост. С.А. Банадысев, А.М. Старовойтов, И.И. Колядко [и др.]. Минск, 2003. 72 с.

6. Методические указания по технологии селекционного процесса картофреля / сост. Е.А. Симакова, Н.П. Склярова, И.М. Яшина. M., 2006. $70 \mathrm{C}$.
7. Методические указания по оценке сортов картофеля на пригодность к переработке и хранению / сост. К.А. Пшеченков, О.Н. Давыденкова, В.И. Седова [и др.]. М.: ВНИИКХ, 2008. 39 c.

8. Методические указания по поддержанию и изучению мировой коллекции картофеля / сост. С.Д. Киру, Л.И. Костина, Э.В. Трускинов [и др.]. СПб., 2010. 32 с.

9. ГОСТ 31640-2012. Корма. Методы определения сухого вещества. М.: Стандартинформ, $2012.7 \mathrm{c}$.

10. ГОСТ 8756.13-87. Продукты переработки плодов и овощей. Методы определения сахаров. М. : Стандартинформ, 2010.10 C.

11. Кордабовский В.Ю. Новые скороспелые сортообразцы картофреля // Международный научно-исследовательский журнал. 2016. № 6 (48). Ч. 5. С. 175-176.

12. Шестрюкова Т.П., Иващенко А.Д. Результаты комплексной оценки коллекционных сортов картофреля в условиях Камчатского края // Дальневосточный аграрный вестник. 2015. № 3 (31). С. 64-68.

13. Кулинарные качества // Качество картофеля и картофелепродуктов / под ред. А.В. Коршунова. М., 2001. С. 17-26.

14. Ким И.В. Исходный материал для селекции картофреля на продуктивность и высокие потребительские качества в условиях Приморского края : дис. ... канд. С.-х. наук. СПб., 2012. 132 c.

\section{Literatura}

1. Simakov E.A., Anisimov B.V., Mitjushkin A.V. i dr. Kartofel' dlja pererabotki: parametry kachestva, special'nye sorta, osobennosti vyrashhivanija. Cheboksary: Aster, 2019. 40 s.

2. Gajzatulin A.S., Mitjushkin A.V., Zhuravlev A.A. i dr. Podbor i ocenka ishodnogo materiala $v$ selekcii kartofelja na prigodnost' k pererabotke // Kartofel' i ovoshhi. 2019. № 7. S. 36-40.

3. Gosudarstvennyj reestr selekcionnyh dostizhenij. URL: http://reestr.gossortrf.ru/ reestr/culture/159.html (data obrashhenija: 10.11.2019).

4. Chajka A.K., Klykov A.G. Prioritetnye napravlenija $v$ razvitii agropromyshlennogo ko- 
mpleksa Dal'nego Vostoka Rossii // Vestnik DVO RAN. 2016. № 2. S. 24-30.

5. Metodicheskie rekomendacii po specializirovannoj ocenke sortov kartofelja / sost. S.A. Banadysev, A.M. Starovojtov, I.I. Koljadko [i dr.]. Minsk, 2003. $72 \mathrm{~s}$.

6. Metodicheskie ukazanija po tehnologii selekcionnogo processa kartofelja / sost. E.A. Simakova, N.P. Skljarova, I.M. Jashina. M., 2006. $70 \mathrm{~s}$.

7. Metodicheskie ukazanija po ocenke sortov kartofelja na prigodnost' $\mathrm{k}$ pererabotke i hraneniju I sost. K.A. Pshechenkov, O.N. Davydenkova, V.I. Sedova [i dr.]. M.: VNIIKH, 2008. - $39 \mathrm{~s}$.

8. Metodicheskie ukazanija po podderzhaniju i izucheniju mirovoj kollekcii kartofelja / sost. S.D. Kiru, L.I. Kostina, Je.V. Truskinov [i dr.]. $\mathrm{SPb} ., 2010.32 \mathrm{~s}$.

9. GOST 31640-2012. Korma. Metody opredelenija suhogo veshhestva. M.: Standartinform, 2012. $7 \mathrm{~s}$.
10. GOST 8756.13-87. Produkty pererabotki plodov i ovoshhej. Metody opredelenija saharov. M. : Standartinform, 2010. $10 \mathrm{~s}$.

11. Kordabovskij V.Ju. Novye skorospelye sortoobrazcy kartofelja // Mezhdunarodnyj nauchno-issledovatel'skij zhurnal. 2016. № 6 (48). Ch. 5. S. 175-176.

12. Shestrjukova T.P., Ivashhenko A.D. Rezul'taty kompleksnoj ocenki kollekcionnyh sortov kartofelja v uslovijah Kamchatskogo kraja /I Dal'nevostochnyj agrarnyj vestnik. 2015. № 3 (31). S. 64-68.

13. Kulinarnye kachestva // Kachestvo kartofelja i kartofeleproduktov / pod red. A.V. Korshunova. M., 2001. S. 17-26.

14. Kim I.V. Ishodnyj material dlja selekcii kartofelja na produktivnost' i vysokie potrebitel'skie kachestva $v$ uslovijah Primorskogo kraja : dis. ... kand. s.-h. nauk. SPb., 2012. $132 \mathrm{~s}$. 